http://dx.doi.org/10.18232/alhe.1125

Artigos

\title{
A capital paulista, suas águas e seu espaço (1890-1940): diferentes ações, um sentido
}

\section{The capital of São Paulo, its waters and its space (1890-1940): different actions, one way}

Fabio Alexandre dos Santos ${ }^{1, *}$ (DD 0000-0003-0537-1444

${ }^{1}$ Universidade Federal de São Paulo, São Paulo, Brasil.

* Correspondencia: fa.santos@unifesp.br

Resumo. Pode-se afirmar que se formou na cidade de São Paulo um "sentido de atuação" urbana constituído por uma orientação privada nas primeiras décadas do século XX? Essa é a hipótese desta reflexão que busca interpretar intervenções públicas e privadas sobre a cidade tendo como eixo norteador as águas, em especial as utilizadas para geração de energia. Isto posto, o objetivo que fundamenta este artigo é apreender a relação e os legados de empresas e agentes públicos na construção desse possível sentido de ocupação urbana que gerou um caráter elitista, excludente e privatista do espaço público. Para isso, são analisados documentos públicos e privados, jornais, além de um balanço historiográfico sobre os temas tratados.

Palavras-chave: São Paulo (cidade); urbanização; águas; mercadoria.

Abstract. Can it be said that an urban "sense of action" was formed in the city of São Paulo, constituted by a private orientation in the first decades of the twentieth century? This is the hypothesis of this reflection that seeks to interpret public and private interventions on the city having as its guiding axis the waters, especially those used for power generation. That said, the objective behind this article is to grasp the relationship

CÓMO CITAR: Santos, F. A. dos (2021). A capital paulista, suas águas e seu espaço (1890-1940): diferentes ações, um sentido. América Latina en la Historia Económica, 28(2), 1-25. DOI:10.18232/alhe.1125 
and legacies of companies and public agents in the construction of this possible sense of urban occupation that generated an elitist, exclusionary and privatist character of public space. For this, public and private documents, newspapers, as well as a historiographical balance on the treated subjects are analyzed.

Key words: São Paulo (city); urbanization; waters; public space; commodity.

JEL: N36; N96; O54.

Recebido: 23 de outubro de 2019.

Aceito: 24 de fevereiro de 2020 .

Publicado: 05 fevereiro de 2021.

\section{INTRODUÇÃO}

A partir do último quartel do século XIX, a cidade de São Paulo passou a vivenciar intensas transformações na sua vida urbana. Conjunturalmente, esse processo estava diretamente vinculado às mudanças estruturais do sistema capitalista em nível mundial, com a industrialização de países considerados adiantados (Estados Unidos, Alemanha e França). O momento foi marcado pela expansão de técnicas industriais e pela difusão de produtos e serviços que assinalariam uma nova "fase" do capitalismo, marcada pelo acirramento da concorrência entre os países centrais do sistema.

Por um lado, eram oportunidades de investimentos que se abriam para aqueles que detinham capitais, por outro, estavam algumas regiões periféricas ávidas por recursos, especialmente para serviços públicos que requeriam grande aporte de capital, como nas principais capitais da América Latina. ${ }^{1}$

No Brasil do século xix, os investimentos externos, acentuadamente ingleses, eram uma realidade, porém na virada para o século xx, diante da consolidação do país nas linhas do mercado internacional e do acirramento da concorrência entre os países centrais do sistema capitalista, houve uma diversificação das origens dos capitais aportados no país. Do início do século xx até a primeira guerra mundial os ingleses perderam a hegemonia nos investimentos realizados no Brasil, resultado da diversificação setorial, expansão industrial e das mudanças nas atividades primárias (Castro, 1979, p. 12). Até 1918, o estado de São Paulo atraiu capital estrangeiro, pois havia excepcionais condições de produção e comercialização de seu produto de exportação (mesmo diante de volatilidades). ${ }^{2}$

${ }^{1}$ Sobre estas questões, a obra de Hobsbawm (1998) é a referência.

${ }^{2}$ Investimentos públicos também contribuíram para entrada de capitais estrangeiros na forma de financiamentos, como foi o caso do empréstimo contraído pelo Rio de Janeiro, de 8.5 milhões de libras, para a remodelação do porto do Rio de Janeiro, as reformas urbanas e as obras sanitárias (Castro, 1979, p. 92). 
Ademais, fatores internos contribuíam com essa atração, reflexos do fim do escravismo, do advento da República e da instauração do federalismo que, em conjunto, ampliaram as condições para inversões em setores ligados aos sistemas exportadores (ferrovias, portos) e à infraestrutura das cidades em desenvolvimento (transportes, iluminação, telefonia, saúde, sistemas de água e esgoto). ${ }^{3}$

No período de 1850 a 1930, o subperíodo de 1911 a 1915 foi o que registrou a maior participação de empresas com capitais estrangeiros em São Paulo (19.59\%) do total das empresas estrangeiras no Brasil. Desse percentual, treze eram de capitais ingleses, seguidas por quatro de franceses, três americanas, dois alemãs e dois canadenses, além de outras nacionalidades (Bovo, 1974). Em São Paulo, esses investimentos aconteceram principalmente no setor bancário e nos serviços de energia elétrica e transporte urbano, de modo a criar as condições para o desenvolvimento de serviços tipicamente urbanos (Saes e Szmrecsányi, 1995, pp. 238-241).

Quanto ao federalismo, deve-se destacar que sua instalação advinda da Constituição de 1891, possibilitou que estados e municípios passassem a deter autonomia financeira, legislativa e administrativa, ao contrário do momento precedente quando suas políticas respondiam, na maioria das vezes, a ações pontuais dependentes dos interesses do Império. Assim, a partir de 1891 os estados e munícipios puderam direcionar suas políticas de acordo com a conjuntura de desenvolvimento e de acumulação que se apresentava em cada um deles, evidentemente que atreladas às suas receitas (Arasawa, 2010, p. 344; Costa, 1998, p. 158).

Na convergência destes fatores, o momento foi propício para São Paulo, dado que os impostos de exportação passaram a ser geridos pelos estados, num momento em que as receitas do setor agroexportador subiram na década de 1890; ademais os fluxos migratórios internos e externos refletiam na ampliação da demanda por novos produtos e serviços públicos e estimulavam a produção de bens de consumo. Estavam postas, assim, as condições para que seus administradores (que tinham a Europa como referência), buscassem instaurar a "modernização" (Berman, 1986) e a “civilização" (Elias, 1994), através de obras urbanas; serviços, como saneamento; ou promovendo as condições para a atuação do capital estrangeiro em determinados serviços.

No que tange às águas que nascem ou atravessam a cidade, a relação dos agentes públicos e privados e mesmo da população com a realidade da virada do século XIX ao Xx, expunha contradições e conflitos. Não são relações estáticas no tempo e no espaço, mas relacionadas dialeticamente com objetivos de cada grupo social em sua complexa rede de variáveis. Destas relações emergem a relação homem e o que se considera natureza, apreendida aqui nas inter-relações (dialéticas) entre ambos, os quais resultam em "ambientes construídos", que se transmutam no tempo histórico sob relações capitalistas de produção, transformando os diferentes elementos do ambiente (construído ou não) em mercadoria (Harvey, 2013, pp. 314-315).

Essas relações, por sua vez, também estão submetidas a aprimoramentos tecnológicos e capitais disponíveis e, por isso mesmo, são capazes de promoverem ressignificações sobre o que se entende por natureza, pois são manifestações culturais que refletem representações e interesses dos homens e de seus respectivos grupos sociais (Martinez, 2006, p. 21; Pádua, 2010, p. 88; Worster, 1991, p. 201).

${ }^{3}$ Szmrecsányi (1986) e Saes (2010, pp. 2-102) chamam a atenção para as relações de interesse que se estabelecem entre os representantes dos estados, que recebiam esses investimentos, e as empresas investidoras, ou seja, para a institucionalização política das condições econômicas e sociais para a acumulação de capital, como concessões, incentivos fiscais, isenções alfandegárias, privilégios etcetera. 
A correlação dos agentes-grupos com a natureza também se encontra nos interstícios das ações dos poderes públicos, materializadas por ações do Estado (Souza, 2006). Assim, tanto no ambiente construído da cidade quanto nas entrelinhas das ações públicas, há elementos a serem apreendidos para o entendimento da problemática em discussão, os quais se materializam em obras públicas e privadas, serviços, regulamentações, etcetera.

Assim, no processo de ocupação do espaço estavam os cursos d'água que, se por um lado conferiram condições para a ocupação e o desenvolvimento da vila à grande cidade que viria a se tornar, abastecendo, alimentando, transportando, comunicando, etc., por outro, essa mesma relação incluía o próprio homem impactando e ou se apropriando das águas como parte do próprio processo de ocupação e utilização dessas águas.

Tendo as águas como eixo condutor desta análise, portanto, pretende-se apreender a construção de um processo de ocupação urbana que, historicamente, direcionou interesses de diferentes agentes - público e privado- de modo a tentar responder se foram capazes de criar um "sentido de ocupação" urbana, ou seja, um padrão de apropriação da cidade pelo capital, ao longo do século $\mathrm{xx}$, em especial nas quatro primeiras décadas.

Esse sentido, aqui amparado em Caio Prado Jr., em Formação do Brasil Contemporâneo, parte da consideração do autor sobre como as funções da colônia portuguesa na América revelaram os resultados do processo de exploração, cujos interesses metropolitanos prevaleceram sobre os internos, transformando as relações internas em "negócio", e cuja percepção foi possível "no conjunto dos fatos e acontecimentos essenciais que a constituíram num longo período de tempo" (Prado Jr., 1997, p. 19).

De certa forma, a historiografia sobre as formas de se produzir converge com a discussão sobre os impactos ambientais dela decorrentes, permitindo vislumbrar a cidade sob o contexto das diferentes fases pelas quais a apropriação do espaço e dos recursos aconteceram. De acordo com Corrêa (2006, p. 66), na origem estão os estudos clássicos de Adolfo Varnhangen sobre o Brasil, na segunda metade do século XIx, quando a paisagem passou a ser tratada como elemento constituinte da identidade nacional. Essa concepção deu lugar às concepções de Capistrano de Abreu e Caio Prado Jr., principalmente, quando incorporaram ao debate as formas de se explorar a paisagem e seus efeitos ambientais. Estes autores interpretaram a apropriação de terras e a exploração como "inevitável e necessário para a civilização e valorização do território". Contudo, na explicação da estruturação produtiva colonial e, em seu sentido histórico, acabaram por se distanciar entre si, pois, se para o primeiro era um "movimento natural", para Caio Prado Jr. era resultado da exploração colonial, ou seja, um padrão constituído no longo prazo.

Por fim, cabe assinalar que os documentos privados e públicos aqui analisados, juntamente com a historiografia sobre os temas abordados, parecem indicar uma predominância de concepções privadas no encaminhamento da construção desse padrão, entretanto, ao dar atenção às ações públicas, verificou-se que administradores públicos e suas respectivas políticas urbanas contribuíram sobremaneira com esse processo. Sob o emaranhado de relações, negócios e interesses que parecem amparar o sentido aqui em discussão, portanto, constituíram-se redes de negócios, como denomina Mehrtens (2003, p. 266), que recriavam padrões.

Isto posto, o objetivo desta reflexão é refletir sobre como obras, loteamentos e intervenções dos setores privado e público expressam a criação de um sentido de atuação urbana, criando e reproduzindo as condições de uma cidade-mercadoria, ou seja, como espaço para reprodução de capital. O marco inicial da análise remonta à década de 1890, quando aspectos externos se fundem com os internos e estabelecem as condições para que os diferentes agentes atuassem na sua urbanização, 
reproduzindo as condições para a "construção" dos problemas urbanos até hoje presentes, como inundações, tamponamentos, poluição de cursos d'água, especulação imobiliária dentre inúmeros outros. A periodização se encerra por volta dos anos 1940, com o início da efetiva atuação de Prestes Maia e o Plano de Avenidas, momento também marcado pela mudança na dinâmica de acumulação. Porém, problemáticas que antecedem e sucedem esse período são analisadas com o intuito de expor argumentos e conclusões.

No caso das inundações e tamponamentos elas são aqui tratadas como constructos humanos, dos quais o primeiro já era conhecido e discutido desde a primeira metade do século XIX e, o segundo, a partir de 1906, quando foi tamponado o primeiro córrego da cidade, o Anhangabaú. Enquanto as cheias se referem a processos geofísicos, as inundações abarcam o resultado de intervenções do homem sobre o meio. As inundações são resultados de diversos fatores que interferem no regime de drenagem das águas numa dada região, criando condições para prejuízos materiais e humanos, desencadeando discussões, planos, obras com altos custos para a sociedade (Custódio, 2012, pp. 194 e ss.; Santos, 2015, pp. 44-45; Seabra, 1987, p. 120 e 1988, p. 21). ${ }^{4}$ Enquanto os tamponamentos -um dos fatores que contribuem para a emergência de inundaçõessão canalizações, entubamentos, encaixotamentos de córregos ou filetes d'água em grandes canos e/ou tubulações abaixo do nível da rua, enterrando-os com o objetivo de se maximizar o uso da superfície para fins urbanos (Santos, 2018, p. 52). Conforme Bartalini (2006, p. 90), sua execução transforma os córregos em meras “peças de uma máquina hidráulica”, permitindo que na superfície as áreas que deveriam cumprir a função de planícies de inundação, tomem a forma de corredores, ruas, avenidas para circulação de veículos.

O texto está dividido em quatro partes. Na primeira pretende-se estabelecer os marcos iniciais da cidade como espaço de inversões; na segunda, a ênfase recai sobre o setor público, em especial a partir da administração de Washington Luís, relacionando-os com o crescimento econômico e urbano; na terceira parte, discute-se o crescimento da cidade em relação à atuação das empresas, principalmente a da Light; e, por fim, as reflexões finais.

\section{A CIDADE, A TERRA, A MERCADORIA}

Situada a leste do estado de São Paulo, a cidade de São Paulo está inserida na chamada região metropolitana de São Paulo (RMSP). Em termos populacionais, de acordo com dados de 2018 do Instituto Brasileiro de Geografia e Estatística (IBGE), a RMSP abrigava nos 39 municípios que a compunha, uma população de 21571281 habitantes que entre 2000 e 2018 registrou uma taxa geométrica de crescimento anual da população de $1.15 \%$. Para efeitos de dimensionamento, a cidade São Paulo, capital do estado (ver em destaque na figura 1), abrigava uma população de 12176866 de habitantes em 2018. Ainda segundo o IBGE, em 2017, o produto interno bruto (PIB) da cidade de São Paulo correspondia a 10.6\% do PIB nacional, seguida pelas cidades do Rio de Janeiro (5.1\%), Brasília (3.7\%), Belo Horizonte (1.4\%), Curitiba (1.3\%), Osasco, cidade da RMSP (1.2\%) e Porto Alegre (1.1\%).

A magnitude populacional e econômica atual da cidade de São Paulo revelam dinâmicas que no conjunto das transformações econômicas e sociais remetem ao século xIx e ajudam a compreender os elementos constituintes de um sentido elaborado e reelaborado ao longo dos anos. Por exemplo,

${ }^{4}$ Veyret (2007, p. 64) destaca que as inundações são aléas que mais estão presentes no planeta, atingindo populações em todos os continentes. 


\section{FIGURA 1. BRASIL, ESTADO DE SÃO PAULO E A CIDADE DE SÃO PAULO E SUA} HIDROGRAFIA

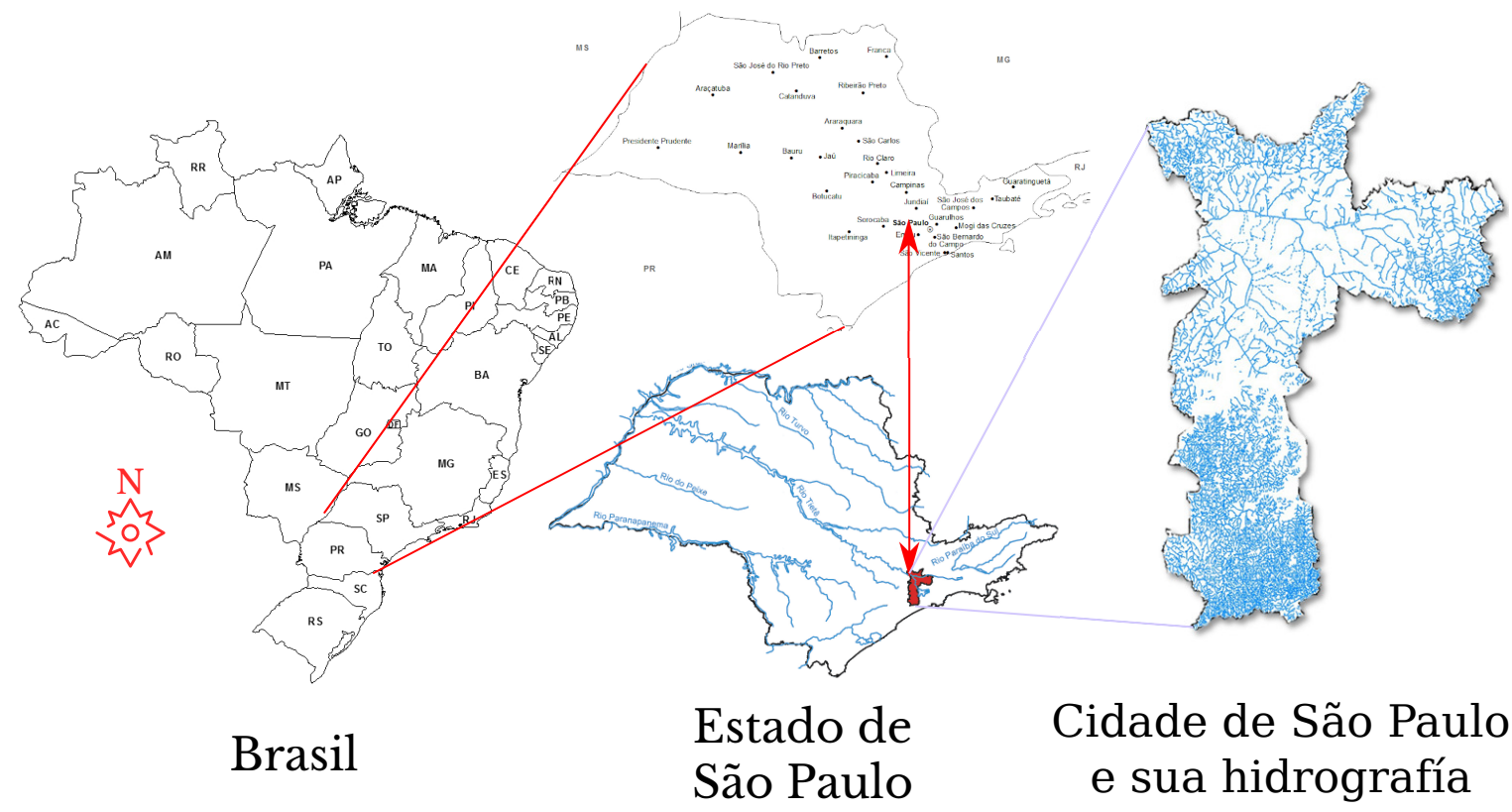

Fontes: Disponível em http://www.mapasparacolorir.com.br/mapa-brasil.php (Acesso em 15 de janeiro de 2015). Estado de São Paulo (hidrográfico). Disponível em http://www.sp-turismo.com/dados.htm (Acesso em 15 de janeiro de 2015). Mapa Hidrográfico da cidade de São Paulo. Disponível em http://atasambiental.prefeitura.sp.gov.br/conteudo/ saneamento/san_06htm (Acesso em 15 de janeiro de 2015).

em 1872, a população da cidade de São Paulo era 31385 habitantes. Ao iniciar a década de 1890, já sob os efeitos das ligações ferroviárias, da imigração e do fim do escravismo, sua população saltou para 64934 habitantes; em 1900, eram 239820 habitantes; em 1920, 579 033; e, em 1940, chegou a 1326261 habitantes (Santos, 1998, p. 137).

O ponto de inflexão dessa explosão demográfica encontra-se na estruturação do que viria a se tornar o complexo econômico cafeeiro paulista que explica a instalação das vias férreas que pela cidade de São Paulo passavam, como intermediária entre as áreas produtoras e o porto de exportação. Seus trilhos, assentados ao nível e ao longo dos percursos dos rios, nos fundos de vale (ponto mais baixo de um relevo acidentado que recebe águas da região em que se está inserida), despertaram atratividade econômica a seu entorno. Se por lado atraiu proprietários de pequenas fábricas, interessados em agilizar a circulação e reduzir custos e, por outro, a oferta de trabalho atraiu trabalhadores. De leste a oeste, muitos loteamentos e ocupações aconteceram em várzeas ou próximas a elas (insalubres) formando bairros operários, como Brás, Mooca, Água Branca.

Da mesma maneira, processos de valorização de áreas segundo sua localização e altitude tomaram forma, assentados na ideia de salubridade que valorizava as terras altas e arejadas (salubres), num cenário de crescimento do mercado imobiliário, com o loteamento de chácaras, sítios e construções de palacetes de fazendeiros, que na capital se instalavam. Esse movimento ressignificou a relação daqueles que possuíam capital com o espaço citadino, transformadas em mercadoria em seu sentido clássico. 
Não em vão que nas primeiras décadas do século xx, a relação entre a ocupação do espaço -como lugar "onde o excesso de capitais superacumulados podem mais facilmente ser absorvidos, criando novos mercados e novas oportunidades para investimentos rentáveis”, como aponta Harvey (2005, p. 116) - e a busca da regularidade do tecido urbano moderno e civilizado foi uma constante que se metamorfoseava de acordo com o momento.

Uma das primeiras manifestações nesse sentido ocorreu sob o Encilhamento (1890-1891), com um primeiro movimento significativo de especulação com imóveis. ${ }^{5}$ Naqueles anos foram criadas companhias nos mais variados setores, porém, a predominância recaiu sobre o setor imobiliário, com atuação de companhias industriais, casas comerciais e bancos. A concorrência foi tão acirrada que as maiores empresas expurgaram as menores do mercado, incentivadas pelo ganho na Bolsa Livre, outra consequência do fenômeno. Em São Paulo, foram 79 empresas criadas no setor terciário, 63 no secundário, 20 no setor primário, isto é, o Encilhamento "tomou a forma urbana” na capital paulista, com predomínio dos setores da construção civil e imobiliário (Lérias, 1988, p. 167).

Ao final da década (1899), instalou-se na cidade a São Paulo Tramway, Light \& Power Company Limited, uma empresa estrangeira de origem canadense com capital aberto, com o objetivo de fornecer serviços de transporte urbano, mas que logo passou a atuar em setores-chave do processo de urbanização, como geração e distribuição de energia elétrica, serviços de gás e telefone.

Formada por capitais canadenses, ingleses e norte-americanos, a Light se amparava na falta de recursos técnicos e financeiros por parte da edilidade para oferecer serviços públicos de grandes magnitudes infraestruturais, aliada à "relutância" do setor privado nacional em investir em serviços públicos, pois preferiam inversões "de retorno mais imediato", como o imobiliário (McDowall, 2008, p. 49).

Sua atuação na cidade, contudo, extrapolou os limites dos serviços públicos (Szmrecsányi, 1986, p. 32). Incorporou terras por meio de aquisições e desapropriações visando futuros negócios, fossem eles para seus projetos hidrelétricos, para infraestrutura ou linhas de bondes (tramways) ou simplesmente para obstruir a ação de concorrentes em áreas em que atuava ou tinha interesse. Outra estratégia foi a valorização de áreas por meio da extensão dos trilhos de bondes, criando vazios urbanos propícios a valorizações ou, ainda, firmando contratos privados com empresas imobiliárias para promover extensões das linhas de bondes, sem a participação de agentes públicos e ou planejamento urbano (Santos, 2011, pp. 238-242).

Outra companhia de capital estrangeiro a instalar-se em São Paulo e que contribuiria com a construção de um sentido foi a City of São Paulo Improvements and Freehold Land Co., em 1911-1912. Composta por capitais franceses e ingleses majoritariamente, tinha entre seus acionistas diversos nomes ligados a bancos estrangeiros, estradas de ferro e da Light, além de políticos locais. Dentre os nomes ligados à cidade e à administração pública estavam Cincinato César da Silva Braga, ex

\footnotetext{
${ }^{5}$ Seu marco inicial foi a política monetária expansionista de Ouro Preto com o objetivo de restabelecer a lealdade de parte dos fazendeiros fluminenses (descontentes com o fim do escravismo), além da tentativa de conquistar a confiança de fazendeiros paulistas devido à não concessão do Federalismo em 1889. Para isso, promoveu expansão monetária por meio de fundos isentos de juros, gerando um movimento especulativo e incentivando a formação de bancos e companhias (Schulz, 1996, pp. 69, 77; Suzigan, 1986, p. 45; Tannuri, 1977, p. 33).
} 
vereador e negociante de terras, e Horácio Belfort Sabino, capitalista, político em São Paulo e proprietário de grandes parcelas de terras na capital, tendo, inclusive, loteado áreas na região do espigão da avenida Paulista, nas áreas Vila Nova Tupi e Vila América. ${ }^{6}$

A Vila América foi loteada em 1910 pela Cia. Edificadora Villa América fundada por Sabino com terras herdadas de seu sogro, Augusto Milliet. Em 1911, a empresa de Sabino adquiriu outros 960000 metros quadrados $\left(\mathrm{m}^{2}\right)$ dos herdeiros do coronel Ferreira da Rosa, da chácara Bella Veneza. Outra parte desta propriedade foi adquirida pelo coronel José Romão Junqueira e Polycarpo Pinto Correa. No ano seguinte, a Cia. City comprou estas terras da Cia. Edificadora Villa América, de Sabino (que era acionista da City); em 1914, adquiriu as terras de José Romão; e, em 1917, as de Polycarpo Correa.

No total, em 1912, a Cia. City detinha cerca de $12380098 \mathrm{~m}^{2}$ de terras (cujos contatos foram mediados por Victor da Silva Freire, diretor de obras do munícipio naquele momento), representando cerca de $37 \%$ da área urbana da cidade de São Paulo naqueles anos (Bacelli, 1982, p. 23).

Dos interstícios dessa negociação, Souza (1988, pp. 100-102) aponta que houve uma valorização curiosa com propósitos específicos na área que deu origem ao primeiro bairro-jardim ${ }^{7} \mathrm{da}$ cidade. Incialmente adquirida pela Cia. Edificadora Villa América por $\$ 389 \mathrm{o} \mathrm{m}^{2}$, foi vendida para a Edouard Fontaine de Laveleye (fundador da Cia. City), por $\$ 778$ o m $^{2}$; Laveleye, por sua vez, as revendeu por $1 \$ 127 \mathrm{~m}^{2}$ para a Cia. City. Vale destacar que nesse período nenhum melhoramento que pudesse justificar tal valorização fora realizado na região. Ainda segundo Souza, o negócio realizado entre Laveleye e a City, pelo valor de $1 \$ 127 \mathrm{o} \mathrm{m}^{2}$ foi pago com debêntures e ações, o que poderia estar relacionada “à própria constituição do capital para o funcionamento da companhia”.

As áreas negociadas deram origem a vários loteamentos entre eles os Jardins, que interessa diretamente aos limites dessa reflexão, pois se situa(va) numa região considerada insalubre, nas imediações do rio Pinheiros, mas que, com a drenagem do terreno, iniciada em 1913, criaram-se as condições para seu loteamento (Souza, 1988, p. 81). Em outro bairro loteado pela Cia. City, o Pacaembu, seu parcelamento aconteceu na década de 1920, o que implicou na canalização e tamponamento do córrego de mesmo nome, executado pela City, e sobre o qual criou-se uma avenida com o objetivo de promover áreas de circulação (Alvim e Corrêa, 2000, p. 103).

Nas composições diretivas da Light e da City conjugavam nomes em comuns e suas trajetórias iriam se cruzar por ocasião da incorporação das terras da City, desapropriadas pela Light no contexto das inundações de 1929, tratadas adiante.

\footnotetext{
${ }^{6}$ Plínio Barreto. Uma temerária aventura forense: a questão entre D. Amália de Moreira Keating e a City of San Paulo Improvements \& Freehold Land Co. Ltd. -allegações finaes do advogado desta última. Revista dos Tribunais (1933) en Souza (1988, p. 34).

${ }^{7}$ Os chamados bairros-jardins insere-se na concepção de cidade de Ebenezer Howard (1850-1928) em que se deveria sanear os bairros insalubres dos centros das grandes metrópoles, fixando o trabalhador à terra e desmobilizando movimentos populares e urbanos. Foram bairros originalmente pensados para trabalhadores, com moradias individuais, articulação entre cidade e natureza, limite para as comunidades de até 30000 pessoas, com salubridade visando uma sociedade igualitária, justa, limpa, saudável (Freitag, 2012, pp. 78-79).
} 
No caso da Light, o encadeamento dos fatores que compunham o crescimento urbano a favorecia, devido à natureza dos seus serviços, na medida em que passava a monopolizar serviços públicos numa cidade em crescimento em que a terra se consolidava como um atraente negócio enquanto a demanda por energia elétrica também era crescente. ${ }^{8}$

\section{PÚBlico E PRIVADO: INTERESSES E CONFLITOS}

As primeiras décadas do século xx revelava, portanto, novas facetas econômicas e sociais a serem enfrentadas pelos poderes públicos, pela população e por aqueles com capacidade de investimentos ante à dinâmica urbana. Havia uma sobreposição de construções e funções que substituía chácaras rurais ou semirrurais por loteamentos, abrindo ruas que suprimiam quintas, cujas funções iam da subsistência à construção de fossas; e, em decorrência do primeiro, para novos usos e funções, cabia a expulsão dos "indesejados" e supressão das habitações e cortiços considerados "insalubres". 9

Com o fim da primeira guerra mundial importantes aspectos econômicos tomaram outras formas. A partir de então a indústria tomaria um caráter distinto daquele em vigor, caracteristicamente complementar e subsidiário do setor exportador, mesmo que ainda dele dependente. A produção industrial passou a responder pela demanda interna por matérias primas e alimentos ligadas às atividades urbanas que cresciam e fomentavam atividades em setores-chave, como cimento, ferro e aço, produtos químicos, equipamentos destinados à agricultura, à indústria e à construção (Suzigan, 1986, pp. 114-115).

No período do conflito Washington Luís Pereira de Souza assumiu a prefeitura (1914-1919) e dentre as políticas públicas e obras que marcariam sua gestão a mais emblemática aos interesses escopo desta análise, foi o saneamento da várzea do Carmo com a construção do Parque D. Pedro II. A proposta era antiga e se alinhava à retificação do rio Tamanduateí, que iniciada em 1896 e concluída em 1914, compondo o conjunto das obras de modernização da região central. Na prática era a oportunidade de suprimir as várzeas e tudo o que era considerado insalubre e nãocivilizado, como as águas paradas, as lavadeiras, as prostitutas e os desocupados que viviam de expedientes temporários ao longo do rio; além de ligar organicamente o centro e a zona industrial em crescimento, do outro lado do rio, disponibilizando espaço ao mercado imobiliário.

Após debates na Câmara e a frustrada tentativa de vender uma área para financiar a obra, em 1916 a prefeitura lançou um edital público para empresas interessadas em sanear e construir o parque. Para tanto, a empresa vencedora receberia como pagamento três quartas partes em terrenos, a 30000 réis o $\mathrm{m}^{2}$ e o restante em títulos da municipalidade em três prestações anuais. A obra foi orçada em 2.276:705\$386 réis (Relatorio de 1916 apresentado á Camara Municipal de São Paulo pelo Prefeito Washington Luís Pereira de Sousa. São Paulo: Casa Vanorden, 1918, p. 48 em Santos, 2011, p. 162).

${ }^{8}$ A empresa também atuou na exploração dos rios extraindo materiais requisitados pela construção civil, como argila, pedregulhos, areia. Tais negócios representavam a incorporação do trabalho social transformado em capital em diferentes vertentes. Como aponta Seabra (1987, p. 85), esse processo adquiriu formas diversas que extrapolavam a própria incorporação da terra, várzea pelo mercado imobiliário.

${ }^{9} \mathrm{~A}$ moradia, cabe destacar, era um tema recorrente das autoridades públicas à aglomeração de pessoas em espaços considerados "perigosos", mas também um dos principais itens na pauta do nascente movimento operário e muito presente entre as reclamações da população publicadas periódicos daqueles anos, os quais não serão aqui abordados. 


\section{MAPA 1. CIDADE DE SÃO PAULO COM DESTAQUE PARA OS RIOS TIETÊ, PINHEIROS E TAMANDUATEÍ, E O PARQUE D. PEDRO II}

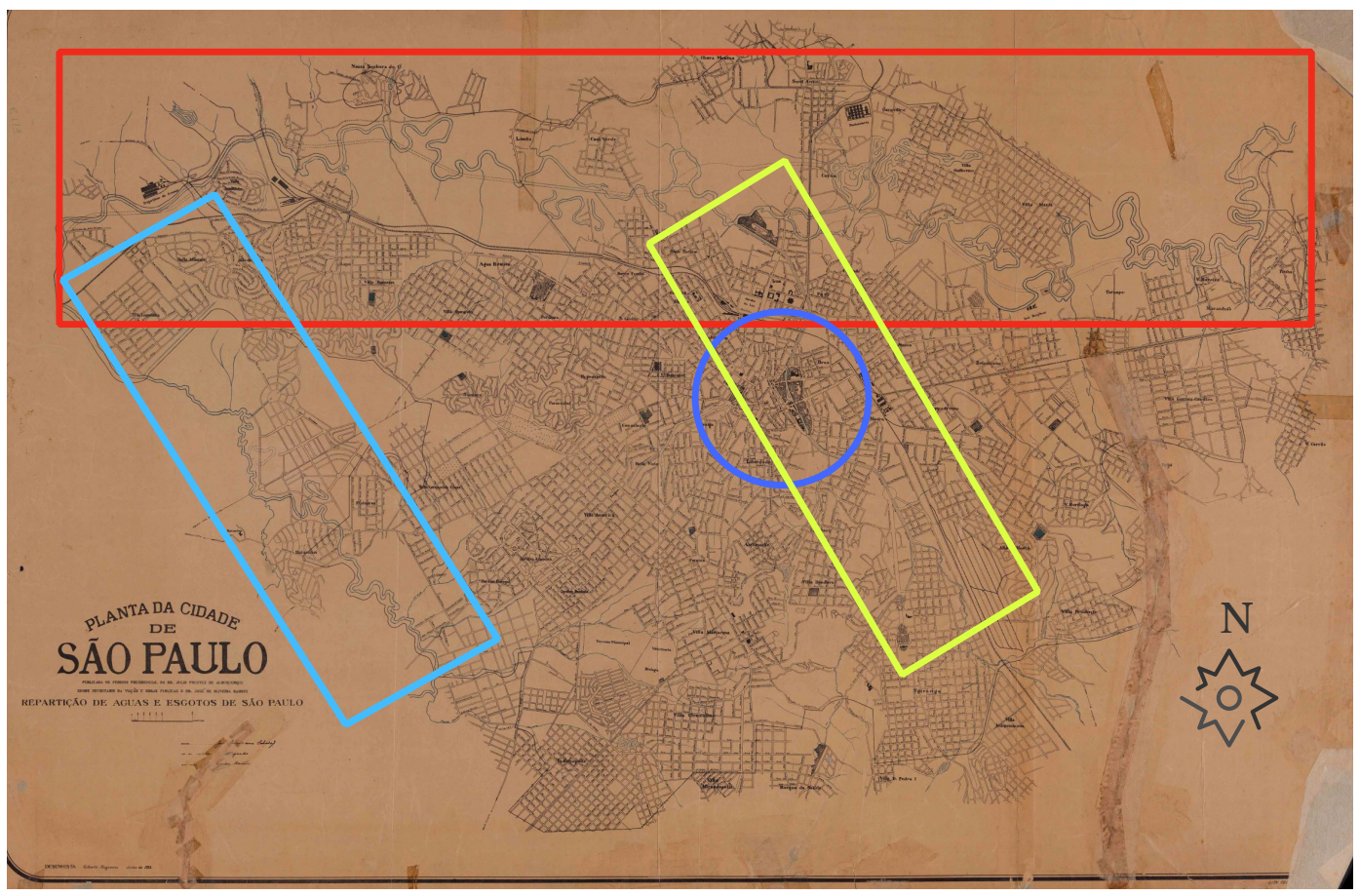
Paulo.

Fonte: Planta da cidade de São Paulo. Repartição de Água e Esgoto (1928). Arquivo Público do estado de São

Criada para a execução dessa obra em setembro de 1918, a Cia. Parque Várzea do Carmo foi a vencedora do edital. A empresa assinou o contrato com a Diretoria de Obras ainda em 1918, com um prazo de 20 meses para sua conclusão. A localização do Parque D. Pedro II pode ser visualizada no mapa 1, no círculo em roxo; os demais destaques se referem aos rios Pinheiros (azul), Tietê (vermelho) e Tamanduateí (amarelo) até então o único dos três principais rios que havia sido retificado.

Dos lotes que recebeu pelo pagamento das obras, realizou o loteamento do entorno da área que abrigaria o futuro Mercado Municipal, em 1922, na atual área da rua 25 de Março. Até 19 de janeiro de 1928, quando a companhia publicou os valores das transações até aquele momento, as vendas totalizavam 7.536:329\$000 (Jornal O Estado de São Paulo, 19 de janeiro de 1928, p. 1 em Santos, 2011). Como demostrado na obra citada que apresenta esta discussão, o resultado, mesmo que bruto, quando comparado ao orçamento inicial de 2.276:705\$386, permite aferir que o empreendimento resultou num lucro bruto à empresa na ordem de 5.259:623\$614 (cinco mil duzentos e cinquenta e nove contos). ${ }^{10}$

\footnotetext{
${ }^{10}$ Iniciada em 1918, a obra foi interrompida com a gripe espanhola e reiniciada em 1920. Foi inaugurada em 1922,
} sob o pretexto das comemorações do Centenário da Independência, mas efetivamente concluída em 1925. 
No tocante à Light, em fins da década de 1920, sua relação com os órgãos públicos alternava embates com ganhos e perdas. Um deles foi o pleito para o aumento das tarifas dos bondes, que desde 1909 gerava conflitos com os diferentes administradores públicos, que não os autorizavam. Como estratégia a empresa propôs, em 1927, a construção de um sistema integrado de transporte -incluindo metrô. No ano seguinte, o Partido Democrático, com um viés nacionalista, formou uma comissão para averiguar a proposta e se posicionou contrário ao plano. No seu relatório encaminhado à Câmara Municipal, a comissão indicou que a Light pretendia modificar "a seu beneficio" o serviço de viação urbana, sendo, por isso, um momento oportuno para "o Poder Público limitar a liberdade de ação" com que operava, incluindo os serviços de "luz e força". A indicação, portanto, foi que a proposta deveria ser analisada em conjunto com a concessão de "luz e força" e que a empresa não deveria ser "privilegiada na operação de ônibus urbanos e que o aumento no preço das passagens deveria estar atrelado a um processo de tomada de contas da Companhia" (Stiel, 1986, p. 62).

Seguido de debates que incluíram um parecer de uma consultoria externa, favorável ao projeto, exceto no que se referia ao monopólio dos serviços, o projeto ainda contava com a oposição de Prestes Maia, ${ }^{11}$ então chefe da Secretaria de Viação e Obras Públicas da prefeitura entre 1926 e 1930, e que havia colaborado com o Plano de Avenidas, com Ulhôa Cintra. ${ }^{12}$ Diante da oposição que predominou, a empresa abandonou o serviço de transportes por bondes, cuja manifestação se deu em 1937, mas efetivamente concretizado em 1947, quando os serviços foram assumidos pela Companhia Municipal de Transportes Coletivos. ${ }^{13}$

O Plano de Avenidas foi gestado em 1922, por Ulhôa Cintra e Prestes Maia e retomado pelo segundo em meados da década, como um estudo sobre problemas urbanos na época. Ele previa a passagem da capital exportadora - centralizada- para uma capital expansionista -símbolo dos tempos industriais. Entre suas prerrogativas estavam a "combinação de um modelo radialperimetral indefinidamente ampliável e a organização de seu movimento centrípeto pelo perímetro de irradiação" (Campos, 2002, pp. 396-397). Com ele, destaque-se, ganhou impulso a ocupação de fundos de vale com a canalização e o tamponamento de córregos que deram lugar às vias de transitáveis. ${ }^{14}$ Entre as "diretrizes" do Plano, destaca Campos, estava a deliberada intensão de estabelecer os "rumos a ser seguidos na evolução urbana da cidade" (Prestes Maia. Plano de Avenidas, 1930 em Campos, 2002, p. 403). O que poderia ser aqui definido como um sentido para a produção capitalista do espaço.

${ }^{11}$ Francisco Prestes Maia era formado em engenharia civil pela Escola Politécnica. Foi prefeito interventor indicado entre 1938-1945 e eleito entre 1961-1965. Atuou, ainda, como professor da Escola Politécnica e com os planos de urbanização do Recife (PE) e de Campos do Jordão, Santos e Campinas (SP).

${ }^{12}$ João Florence de Ulhôa Cintra foi chefe da Seção de Cadastros e Urbanismo da Prefeitura, professor da Escola Politécnica, hoje da Universidade de São Paulo (Poli-usP), na área de hidráulica e saneamento. Durante a primeira gestão de Prestes Maia na prefeitura (1938-1945), Cintra foi diretor de obras do município.

13 Em São Paulo, os serviços telefônicos oferecidos pela Light foi até 1966, quando vendeu à Embratel; e os serviços de gás até 1967, tendo sido encampado pela prefeitura. No Rio de Janeiro, onde a Light também atuou, os serviços de bondes foram encerrados em 1963, com a venda para o estado da Guanabara, da mesma forma que os serviços de gás, em 1968 (McDowall, 2008, p. 492).

${ }^{14}$ É ilustrativo destacar que os tamponamentos se tornaram comuns na cidade a partir de então, com a ocupação dos fundos de vale. Somente na bacia hidrográfica do rio Tamanduateí, as retificações e tamponamentos empreendidos entre as décadas de 1950 e 2000 , resultaram em 176.9 km de cursos d'água tamponados e em 65.5 km de retificações, de um total de $662.5 \mathrm{~km}$ do sistema hidrográfico original (Gouveia, 2016). 
Seus planos não foram plenamente concretizados, em razão da situação interna, com os conflitos políticos da década, a Revolução de 1930 e o fim da política do café com leite e a Revolução Constitucionalista (1932); e, no cenário externo, com queda nas transações internacionais, tanto de mercadorias quanto de investimentos, em razão da crise dos anos 1930 .

A partir de 1935, com Fábio Prado na prefeitura (1934-1938), o Plano adquiriu certa ênfase com a nomeação de Ulhôa Cintra para a chefiar o Departamento de Obras e Serviços Municipais. Sob seu comando, foram priorizadas as obras na região sudoeste da cidade, com abertura das importantes avenidas, pavimentação de logradouros, tratamentos paisagísticos (herança de governos anteriores, inclusive, da gestão Pires do Rio, entre 1926-1930), além dos esforços para a exploração do fundo de vale em direção ao sul, com a regulamentação para a abertura e ocupação da antiga avenida Itororó, hoje 23 de Maio, de modo a integrar regiões e completar o sistema de circulação do Plano, contudo, o perímetro de irradiação não foi executado.

Em 1938, sob o Estado-Novo, ${ }^{15}$ Prestes Maia foi indicado como prefeito de São Paulo, permanecendo até 1945. Entre suas primeiras medidas nomeou Ulhôa Cintra chefe do Departamento de Obras que concluiu as obras iniciadas por Fábio Prado e executou abertura e de ruas, construiu a Ponde Grande, atual Ponte das Bandeiras, ultrapassando o rio Tietê e dando forma ao sistema Y do seu Plano (Campos, 2002, pp. 578 e ss.). Além de iniciar as obras de retificação do rio Tietê, cuja conclusão se daria apenas na década de 1960.

A despeito das atuações dos poderes públicos -com propósitos regulamentadores e saneadores desde o século xix, por meio das comissões, estudos, posturas, decretos, leis, padrões, serviços e códigos sanitários, ${ }^{16}$ planos urbanísticos ou reformas sob diferentes administrações-, não se revelaram processos de planejamento urbano capazes de equacionar os problemas da cidade em seu conjunto e complexidade, atendendo à questão da moradia, saneamento, circulação, por exemplo, que mais tarde se tornariam grandes problemas da cidade; ademais, a relação entre estado e municípios ainda incluíam conflitos de poderes. ${ }^{17}$

No caso das reformas urbanas, por exemplo, baseadas nas remodelações promovidas pelo Barão Haussmann, em Paris, ${ }^{18}$ e que inspiraram remodelações em diversas cidades do mundo, elas eram mobilizadas por fatores políticos e econômicos, claro, mas os possíveis planejamentos não

${ }^{15}$ Grosso modo, o Estado Novo (1937-1945) com Getúlio Vargas na presidência do país, foi marcado por um regime político de centralização do poder, autoritarismo, nacionalismo e, ao mesmo tempo, de políticas de promoção da industrialização do país.

${ }^{16}$ Marcada por diferenças regionais, a instauração dos serviços sanitários e de saúde foram assimétricas no Brasil. Em termos comparativos, somente o Rio de Janeiro, capital do país, teve serviços compatíveis com os do estado de São Paulo no início do século xx (Merhy, 1987).

${ }^{17}$ Uma expressão de conflito apareceu quando em 1896 o Serviço Sanitário (criado em 1894) passou por mudanças, pois até então conflitos surgiam quando estado e municípios tinham que atuar em conjunto e as dúvidas sobre a quem caberia ou não a ação sempre emergia. Assim, definiu-se que aos municípios caberia o saneamento básico (água, esgoto, drenagem etc.); o policiamento sanitário das habitações coletivas ou não; a fiscalização de fábricas, estabelecimentos comerciais e alimentação pública; a vacinação; e a assistência aos indigentes, enquanto ao estado coube a organização e execução das intervenções mais "agressivas ou defensivas" no caso de epidemias; o controle e a organização das ações por meio dos inspetores sanitários do estado (antes era atribuição dos municípios). Em 1906, diante de novas reformas, os municípios perderam autonomia quanto à saúde e ao saneamento, reflexo das mudanças nas relações de poder entre estado e municípios. Havia se esgotado o reconhecimento da autonomia municipal como a essência do republicanismo (Telarolli, 1996, pp. 233-234).

18 Napoleão III se baseou nas reformas inglesas para implementar na capital francesa renovações urbanas que instaurassem a "ordem" ao mesmo tempo em que embelezava e promovia serviços urbanos. Implementada pelo barão Haussmann (entre 1853 e 1870). Mas não somente as grandes cidades e capitais foram alvo de obras modernizan- 
abarcavam os indesejáveis. A grande questão era transpor para o espaço físico das cidades as prerrogativas da ordem, do progresso, do embelezamento, por mais que também incluíssem serviços de saneamento, transportes, iluminação, etcetera.

Nesse sentido, um estudo que talvez possa se aproximar de uma análise de conjunto, como um possível planejamento urbano, foi realizado pela comissão chefiada pelo engenheiro sanitarista Saturnino de Brito $^{19}$ que, em 1924, ao se retomar uma antiga discussão sobre a retificação do rio Tietê, elaborou um relatório para a prefeitura sobre as condições hídricas da região, levando em conta os diferentes usos das águas. As conclusões (apresentadas em 1926) resultaram em propostas de intervenções e na reafirmação da necessidade de retificação do Tietê como medidas para sanar o problema das inundações e sanear suas águas. Ademais, as obras incluíam navegação, ocupação de seu entorno, construção de praças, uso das águas para abastecimento humano, preservação de várzeas para regulação natural de vazão, áreas de recreação etc. Suas propostas, entretanto, não foram levadas adiante, tendo sido reformuladas durante a administração de José Pires do Rio (19261930), quando a comissão passou a ser chefiada pelo engenheiro Ulhôa Cintra, que reformulou o projeto e abandonou a ideia de parques e reservatórios naturais recomendados por Saturnino de Brito, atrelando a retificação a concepções de cunho viário, de acordo com as propostas que tinha elaborado em 1922, como citado anteriormente.

Na América Latina, Romero (2009, pp. 283-352) baliza o último quartel do século xIX como o início de um período de transição do que classifica como "cidade patrícia" (1830-1880) em direção à "cidade burguesa” (1880-1930), que implicava em incorporar os símbolos do urbanismo europeu, em especial o francês. Buenos Aires, Montevidéu, Rio de Janeiro, São Paulo foram cidades cujas administrações públicas promoveram tais reformas.

Guardadas as devidas especificidades nas remodelações de cada uma delas, o aspecto salubridade (físico e moral) se destaca como elemento comum entre elas, com aberturas de ruas, construções de praças e largos e, com elas, expulsões dos indesejáveis das áreas centrais. O Rio de Janeiro, então capital federal, teve sua experiência com Pereira Passos, durante o governo de Rodrigues Alves (1902-1906), que lhe rendeu a alcunha de Bota-abaixo, ao suprimir construções consideradas atrasadas (coloniais) e promover o embelezamento que caberia a uma capital "moderna”, abrindo a avenida Central e expulsando "pretos, pobres e vagabundos" da região a ser europeizada, ${ }^{20}$ ou seja, higienizada. ${ }^{21}$ Em São Paulo, obras embelezadoras já haviam tomado forma em meados do século XIX, no rio Tamanduateí, como a construção da Ilha dos Amores (construída em 1875 com jardins e quiosques, mas com a poluição do rio e as inundações, ela foi extinta em 1914) e sua retificação, por exemplo. Paralela às obras no Rio, e sob a administração de Antônio Prado

tes, estando elas direta ou indiretamente ligadas às atividades agroexportadoras, localidades relativamente menores como Santos, Campinas, Ribeirão Preto, Rio Claro, Franca (SP) dentre outras, também foram áreas submetidas a essa lógica.

${ }^{19}$ Francisco Saturnino Rodrigues de Brito cursou engenharia civil na Escola Politécnica do Rio de Janeiro, exerceu cargos em companhias ferroviárias, mas se destacou como engenheiro sanitário atuando no planejamento de projetos de saneamento e abastecimento de água em cidades como São Paulo, Belo Horizonte, Vitória, Rio de Janeiro dentre outras.

${ }^{20}$ As obras do Rio de Janeiro influenciariam reformas em várias capitais, como Salvador (1912-1916), Recife, na década de 1910, Porto Alegre (1914-1920), Petrópolis (RJ) (Campos, 2002, pp. 136-139).

${ }^{21} \mathrm{O}$ caso do Rio de Janeiro, contudo, é emblemático, pois seu resultado ao invés de anteder aos requisitos de contrarrevolução, com previu Haussmann para Paris, elas resultaram na Revolta da Vacina (1904), um movimento popular contrário à vacinação contra a varíola, o que no fundo era uma luta contra as reformas e, nela inserida, contra a higienização dos corpos e do espaço. Para essa questão ver especialmente Chalhoub (1996); Needel (1993). 
(1899-1911), remodelações foram realizadas no centro, com destaque para a construção do Teatro Municipal, inaugurado em 1911. ${ }^{22}$ Essa intencionalidade se manteria sob as administrações seguintes.

Em Buenos Aires, em termos comparativos, seu processo reformista teve início por volta de 1880, com a federalização associada à expansão econômica e ao aumento dos investimentos externos (principalmente britânicos). Com Torcuato de Alvear, iniciou-se as demolições (como a Recova Vieja), a aberturas de ruas (como a avenida de Mayo), construções praças e construções de modernos prédios (Romero, 2009, p. 311). Entre 1935-1937, agregando novas reformas, ela passou a ser chamada de "Paris das Américas" (Needel, 1993, pp. 49 e ss.).

Quanto a planejamento urbano, nem mesmo o Plano de Avenidas poderia ser considerado uma exceção, pois como afirma Campos (2002, p. 404), não apresentava um arcabouço legal que respaldasse suas propostas, e, sim, um olhar "parcial que abstraía as contradições presentes no espaço urbano", da mesma forma que projetos similares em várias capitais e cidades eram executadas sem considerar as condições estruturais da desigualdade brasileira.

No que tange ao setor de energia, a década de 1930, sob Getúlio Vargas e os realinhamentos políticos que se seguiram, as empresas do setor passaram a enfrentar alterações legais que atingiam diretamente suas receitas, por conta de uma legislação voltada "para dentro". Uma delas foi o Decreto 20.395, de 15 de setembro de 1931, que suspendia as alienações, oneração ou transferência de cursos ou quedas d'água e conferia apenas ao governo federal a premissa de autorizar a exploração hidráulica, o que fora ratificado com a Constituição de 1934.

Um segundo decreto, desta vez de novembro de 1933 sob no. 23.501, o governo federal extinguiu a cláusula-ouro que conferia às empresas do setor elétrico o direito de aplicarem correção monetária ante à depreciação monetária na cobrança de tarifas de eletricidade. A partir de então as tarifas passaram ser corrigidas considerando os custos operacionais, sem correções. Ela foi devidamente regulamentada somente em 1941 e, em 1964, ela seria alterada com a introdução da correção monetária do ativo imobilizado (Iannone, 2006, pp. 66-67).

Um terceiro ato foi o Decreto 24.643 de 10 de julho de 1934, instaurando o Código de Águas, que definiu a separação entre o direito de propriedade do solo e o dos recursos hídricos existentes na superfície, os quais se tornaram objeto de concessão e fiscalização por parte do governo e com as tarifas amparadas no investimento realizado. Evidentemente que toda essa legislação era alvo de oposição por parte das empresas do setor elétrico.

O aumento da atuação federal, ora regulando, ora intervindo ora, ainda, promovendo condições para o uso e apropriação de recursos naturais e de espaços urbanos, paralelo ao crescimento na demanda, caminhavam assimetricamente aos investimentos da Light, cujo resultado foi a eclosão de crises de fornecimento já em 1924.

${ }^{22}$ No estado de São Paulo não somente a capital foi alvo de obras modernizadoras, desde que estivessem direta ou indiretamente ligadas às atividades agroexportadoras; localidades relativamente menores como Santos, Campinas, Ribeirão Preto, Rio Claro, Franca dentre outras, também foram áreas submetidas a essa lógica, proporcionalmente às suas capacidades de investimento. 


\section{Crescimento URBANO-INDUSTRIAL, ENERGIA ELÉTRICA E ÁGUAS}

Na década de 1920 a distribuição (venda) de eletricidade por parte da Light adquiriu maior expressão no conjunto de sua receita. Até então, seus negócios estavam majoritariamente voltados ao transporte público e, a energia, era quase um insumo para o funcionamento do primeiro (Saes, 1986, p. 29).

A energia gerada era originária de um complexo formado pela usina instalada em Santana do Parnaíba, em funcionamento desde 1901, da usina Lavras, em Salto (de 1906), e da usina de Itupararanga (de 1914) que, em conjunto com a represa de Guarapiranga (construída em 1908), conferiam à Light os meios para interferir no regime hidrológico da bacia do Alto Tietê, pois, por meio das águas acumuladas na represa de Guarapiranga, era possível aumentar a vazão em direção à usina de Santana de Parnaíba, localizada a 33 quilômetros $(\mathrm{km})$ à jusante de São Paulo, através do rio Pinheiros (afluente do rio Tietê). O rio Pinheiros, assim, tinha a função estratégica de interligar o reservatório do Guarapiranga ao Tietê, por isso "peça-chave" para os negócios da empresa. Contudo, na segunda metade da década de 1920, o rio Pinheiros se transformaria em via fluvial de mão dupla entre o Tietê e o Guarapiranga e a represa Billings (de 1927), construída como parte do Projeto da Serra, como se verá adiante.

Ao lado da Amforp ${ }^{23}$ e com ela concorrendo por áreas de concessão, a Light era uma das principais empresas a fornecer energia no estado de São Paulo na década de 1930, atendendo, além da cidade de São Paulo, as cidades de Santana do Parnaíba, São Roque, Sorocaba, Salto, São Bernardo do Campo, Santo Amaro, ${ }^{24}$ Guarulhos, Ibiúna, Jundiaí, Araraquara, região do Vale do Paraíba, além do Rio de Janeiro (Iannone, 2006, pp. 42-43, 60-62). Mas um de seus principais mercados era a região da capital paulista, atrelado, mesmo que ainda incipientemente, à industrialização em fase inicial.

Nas primeiras décadas do século xx, a ocupação espacial da capital paulista se concentrava na região central, seguida pela ocupação de suas franjas tendendo a leste e a sul-sudoeste, rumando ao sul; nos anos 1930-1940, a mancha de ocupação foi limitada pela "fronteira" dada pelo rio Pinheiros, enquanto a leste, esta característica também marcou a região, com a limitação imposta pelo rio Tietê (que assinalaria a fronteira da cidade); quanto ao norte, a ocupação neste período já havia ultrapassado o rio Tietê (ver mapa 2).

No caso das áreas localizadas na região sudoeste da cidade, especificamente ao longo do rio Pinheiros, de São Paulo a Santo Amaro, limite entre ambas as cidades (ver mapa 3), a atuação da Light se revelou de forma mais intensa. Nesta região se localiza o atual bairro do Brooklyn, cujo processo de loteamento e comercialização foi iniciado na década de 1920, inclusive sua denominação se deve à atuação da companhia na região. Nesta área, ao longo do rio Pinheiros, a empresa "incorporou" uma parcela considerável de terras por ocasião das inundações de 1929.

${ }^{23}$ Em 1927 aportou no Brasil a norte-americana American and Foreign Power Company Inc. (Amforp) criada em 1923 e presente em mais onze países. Era uma filial do Grupo Electric Bond and Share Co. (Ebasco), que por sua vez era uma subsidiária da General Electric (GE). A Amforp fundou a Empresas Elétricas Brasileiras (EEB), depois chamada de Companhia Auxiliar de Empresas Elétricas Brasileiras (СAEeb). Desde o início de sua atuação foi adquirindo o controle acionário de pequenas empresas no interior do estado de São Paulo e em outras cidades e capitais brasileiras, como Natal, Recife, Maceió, Salvador, Vitória, Belo Horizonte, Niterói, Petrópolis, Curitiba, Porto Alegre e Pelotas (Iannone, 2006, p. 43).

${ }^{24}$ A cidade de Santo Amaro foi incorporada como bairro pelo município de São Paulo em 1935. 


\section{MAPA 2. ÁREAS DE OCUPAÇÃO (URBANIZADA) NA CIDADE DE SÃO PAULO, 1915-1949}
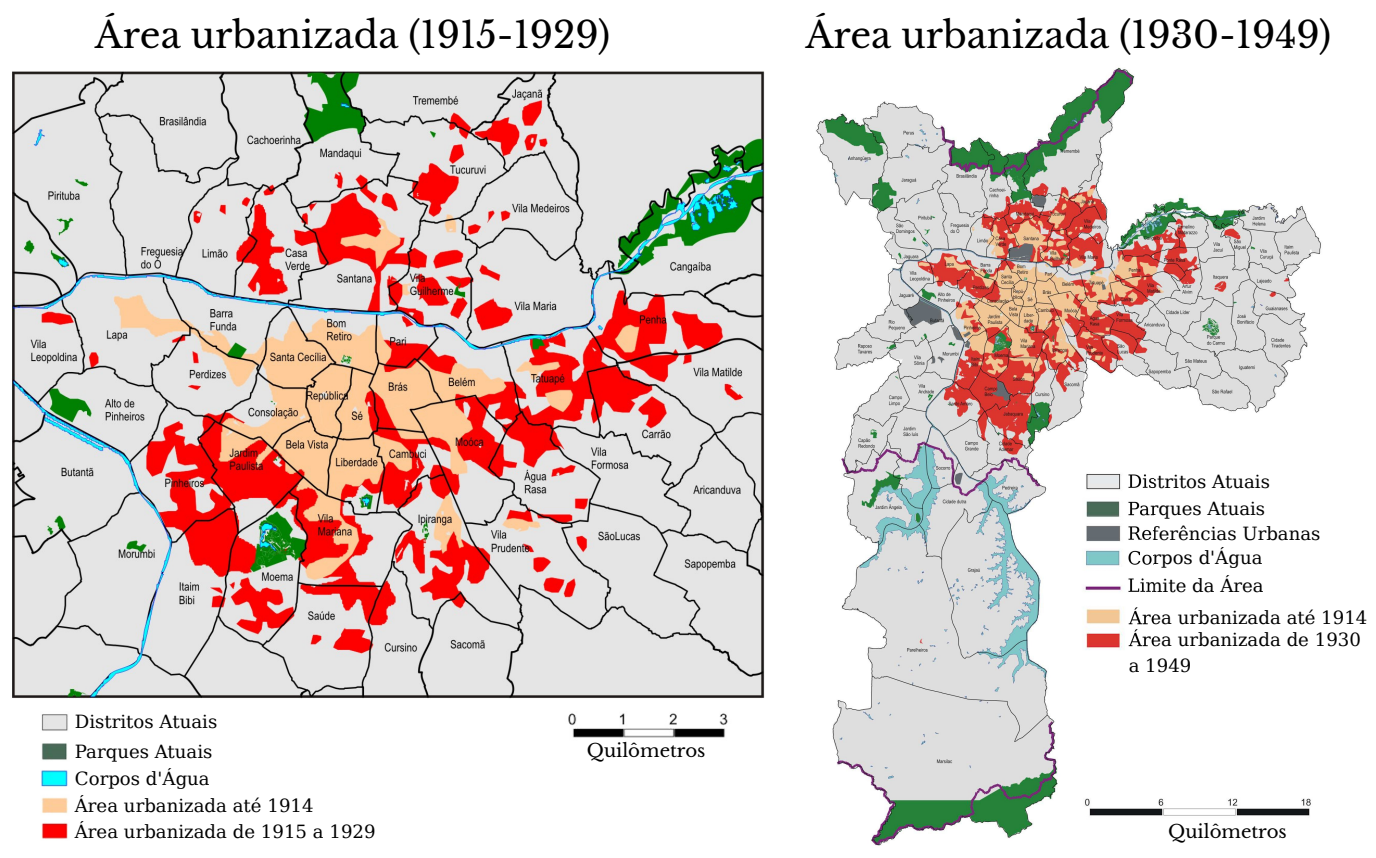

Fontes: Mapas 1920 y 1940, disponível em http://smul.prefeitura.sp.gov.br/historico_demografico/img/mapas/ urb-1920.jpg; http://smul.prefeitura.sp.gov.br/historico_demografico/img/mapas/urb- 1940.jpg (Acesso em 23 de fevereiro de 2018). Os rios Pinheiros e Tietê estão representados na sua forma atual, ou seja, retificados.

De modo sucinto, dado os limites aqui impostos, a inundação de $1929^{25}$ encontra parte de sua explicação na seca de 1924, que atingiu a geração e ameaçou a oferta de energia. Foi quando a Light direcionou seus esforços para ampliar sua capacidade geradora e construiu a usina de Rasgão, em 1925, localizada em Pirapora do Bom Jesus, com capacidade de 23.8 MW e iniciou os procedimentos para a construção da usina de Cubatão, inaugurada parcialmente em 1926. Em 1927 concluiu a represa Billings e obteve a concessão para canalizar, sanear e inverter o curso do rio Pinheiros para utilizar as águas excedentes do rio Tietê para geração de energia na usina em Cubatão, além de desapropriar as áreas inundáveis para serem saneadas e construir a estrutura

25 Após vários dias de chuvas em fevereiro de 1929, no dia 18, após cinco dias sem precipitações nas cabeceiras dos principais rios, houve o registro de uma grande "enchente". Esse fenômeno é tratado por considerável parcela da historiografia como um ato deliberado da empresa, na medida em que a Light abriu as comportas dos reservatórios rio Grande (Billings) e Guarapiranga no dia 14, enquanto na barragem à jusante, na usina de Santana do Parnaíba, suas comportas permaneceram fechadas. Estes atos teriam motivado a inundação, conforme apontam estudos que se dedicaram ao tema, enfatizando os ganhos econômicos do ato (Ferla, et.al, 2014; Jorge, 2006, p. 83; Santos, 2011; Seabra, 1987, dentre outros). Diferentemente, o engenheiro Reynaldo Maffey afirma que a Light não teria "potencializado" as enchentes naqueles dias e, sim, tomado uma decisão técnica para não prejudicar as obras de retificação em andamento, pois a barragem do rio Grande estava em construção e aquém de sua estrutura (que também recebia as águas do reservatório rio Grande e estava sob o risco de transbordamento). Por isso decidiu abrir as comportas instaladas nas futuras unidades de bombeamento, assim como do reservatório de Guarapiranga, que se encontrava cheio (Maffey, 1995). 


\section{MAPA 3. SÃO PAULO, ÁREA INUNDADA EM 1929}

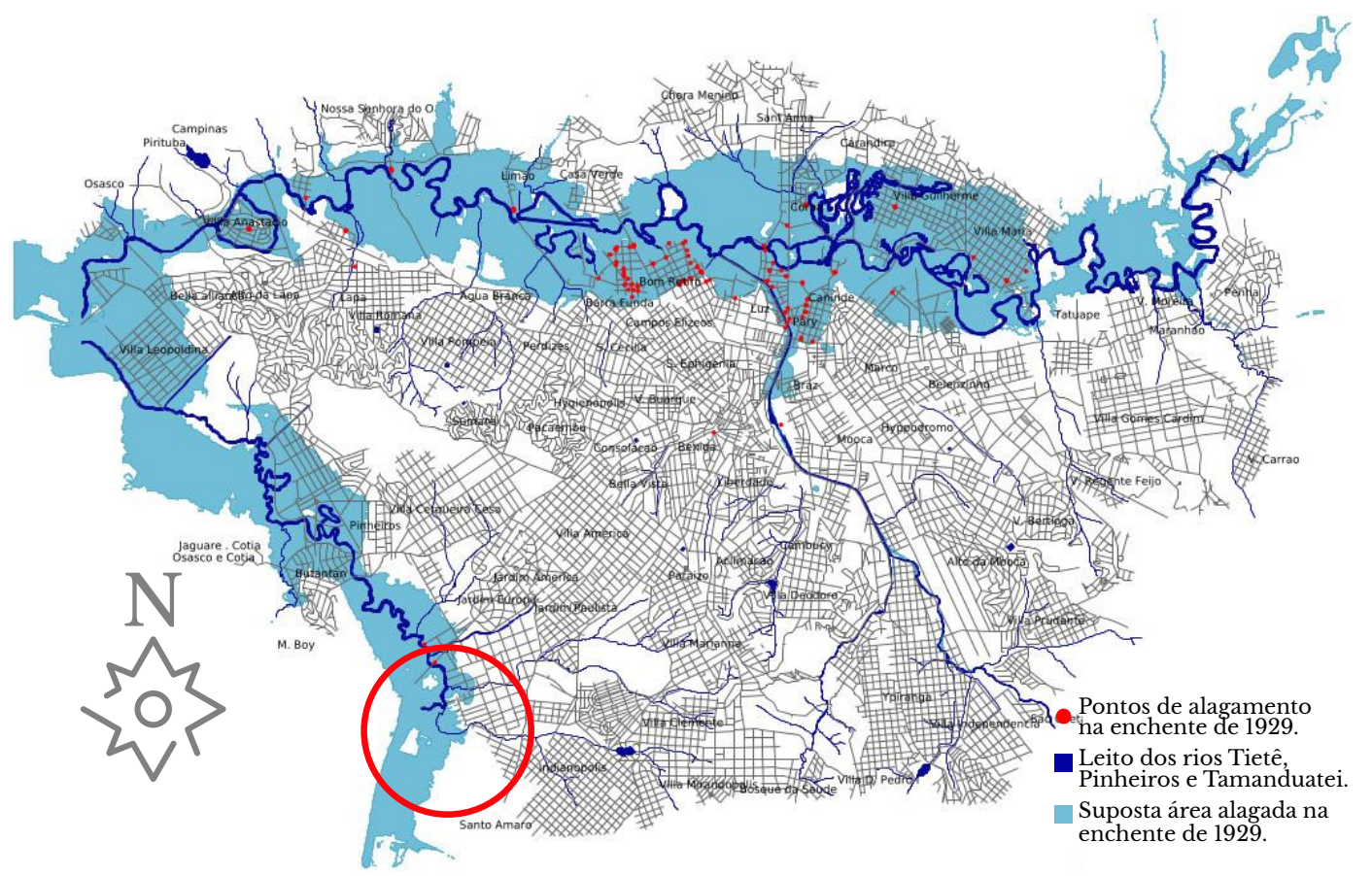

Nota: em um círculo Região do rio Pinheiros em que se encontram os córregos do Cordeiro, Águas Espraiadas e da Traição; e onde se localiza o bairro do Brooklin; até 1935, fronteira entre os municípios de São Paulo e Santo Amaro.

Fonte: Ferla et al. (2014, p. 162).

necessária para sua operação, era o Projeto da Serra. Estavam postas, portanto, as condições para a concretização da via fluvial de mão dupla -represas Guarapiranga e Billings com o rio Tietê- para uso exclusivo da Light, conforme suas necessidades de geração (ver figura 2).

Os fatos decorrentes das inundações de 1929 e das intervenções que se seguiram sobre o rio Pinheiros e adjacências se espraiaram em diferentes dimensões. Uma delas se deu no campo das desapropriações das terras atingidas pela inundação, em benefício da Light, amparada no direito de declarar utilidade pública as áreas "alagadiças ou sujeitas a inundações" (Câmara, 1927; Senado, 1927). As negociações acerca dessas desapropriações envolveram diferentes abordagens da Light para cada proprietário e ou classe social, como apontado por Seabra (1998) e Pontes (1995), reproduzindo um sentido de atuação sobre o espaço e seus moradores e ou proprietários.

Mesmo diante de muita polêmica nos anos que sucederam a inundação e a promulgação do Código de Águas de 1934 (que estipulava linha média de enchentes para fins de desapropriação), a Light conseguiu manter as cláusulas do contrato de concessão e tomou posse das terras atingidas pelas inundações e não pela sua linha média, como mostra o mapa a seguir, com a projeção da inundação. Seu sucesso, segundo Pontes, ocorreu devido ao poder de lobby da empresa para com os poderes públicos, “contrariando a legislação federal” (Pontes, 1995, p. 27). 
Quanto às negociações para efetivar a apropriação das áreas inundadas, a Light fechou com a Cia. City, por exemplo, proprietária de terras na região onde se encontra hoje os bairros "Jardins", um acordo para ressarci-la através do empreendimento de uma linha de bondes no bairro do Pacaembu, ${ }^{26}$ que estava em processo de comercialização. Aos pequenos proprietários coube fechar acordos individuais de desapropriação, aos quais se impunham cláusulas em que renunciavam ao direito prioritário de compra em hasta pública após saneamento da área, como preconizava a lei de concessão.

No aspecto da incorporação das terras, no total, considerando as desapropriações das áreas inundáveis, a Light absorveu ao seu patrimônio um total de $20779443 \mathrm{~m}^{2}$ de áreas contíguas ao rio Pinheiros, sendo que $4015360 \mathrm{~m}^{2}$ receberam algum tipo de obra, como retificação, canal, linhas de transmissão, estrada de ferro ou avenidas. Do restante, $16764083 \mathrm{~m}^{2}$, apenas 10\% retornaram aos antigos proprietários (Ab’Sáber, 1958, p. 210).

Após as obras de retificação (canalização) e saneamento das curvas e várzeas do rio Pinheiros, finalizadas ao final da década de 1950, estavam ampliadas as condições para a ocupação do seu entorno, principalmente da margem esquerda, na medida em que suprimiu várzeas e regularizou seu traçado. A margem esquerda, considerando o sentido original do rio, abrigaria o atual bairro do Morumbi, o Jóquei Clube, a Cidade Universitária da Universidade de São Paulo, o bairro do Jaguaré; e, pela margem direita, partindo de Santo Amaro, o bairro do Brooklyn, a atual Vila Olímpia, os bairros Jardins (obra da Cia. City), a atual região onde foi instalada a Companhia de Entrepostos e Armazéns Gerais de São Paulo (Ceagesp) nos anos 1960.

Para se ter uma ideia, em seu curso original (sem as intervenções), o rio Pinheiros era marcado por uma sinuosidade que totalizava 43000 metros, considerando o rio Grande, e sua planície de inundação (suas várzeas) correspondiam a 25 milhões de $\mathrm{m}^{2}$. Quando retificado, da confluência com o Tietê à barragem do rio Grande (no alto da Serra), passou a 25800 metros de planícies de inundação (Seabra, 1987, p. 70).

A comercialização das áreas saneadas no entorno do rio Pinheiros, sob o domínio da Light, se iniciou em 1952 com a criação de uma seção administrativa especialmente dedicada a esta finalidade, intitulada Seção de Terrenos do Vale do Pinheiros (TVP). Segundo declaração da Light (The São Paulo Tramway, Light \& Power Co. Ltd., 1952, p. 1A) do total de áreas saneadas, parte foi devolvida a antigos proprietários, como compensação ou em função de direito de propriedade, restando um saldo, portanto, que a pertencia tanto em razão de compra quanto em razão de ser “terra do rio". Até 1964, quando se tem o último registro dessas vendas, a empresa havia comercializado $13175779.03 \mathrm{~m}^{2}$ de terras, num total de 710 escrituras negociadas, equivalente a Cr\$ 1494555 442.90, (para se ter uma noção, correspondente a US\$ 928 295.31), dos quais havia recebido em dinheiro Cr\$ 1383962991.80 (ou US\$ 859 604.34), ${ }^{27}$ isto é, 92\% do valor total negociado (The São Paulo Tramway, Light \& Power Co. Ltd., 1964, p. 148).

Como contrapartida, a empresa deveria dispor de parte da extensão saneada para a conservação de taludes, manutenção de sistema e área para a abertura de avenidas marginais ao rio. Assim, em julho de 1957, com a conclusão das obras, foi repassado ao estado as áreas marginas ao rio

${ }^{26}$ Sobre o bairro do Pacaembu e, em especial, a construção do estádio do Pacaembu ver Mehrtens (2003), que centraliza sua análise nas relações estabelecidas entre a Cia. City e a municipalidade, em especial na gestão de Fábio Prado (1934-1938). Para a autora, a partir do Estado Novo, uma nova fase urbanística se processou na cidade, a partir de uma nova geração de técnicos, engenheiros, políticos etc. gestados nos anos 1930.

27 Valores nominais de 22 de dezembro de 1964, ao câmbio do dia, de Cr\$1 610.00 por dólar (Jornal Folha de S. Paulo, 1964, p. 8). 
(The São Paulo Tramway, Light \& Power Co. Ltd., 1958, p. 92) que, segundo a visão efusiva do Jornal O Estado de S. Paulo (20 de Julho de 1957, p. 9), a obra era "de grande importancia para a produção de energia eletrica, seu objetivo precipuo, trazendo também grande beneficio para os terrenos marginais, contribuindo para o seu saneamento e evitando as periodicas inundações e suas danosas consequências".

Tais obras demonstram, assim, como a Light desenvolveu as condições para o domínio das águas da bacia do Alto Tietê, que se por um lado atendia à ampliação da oferta de energia necessária ao desenvolvimento industrial, por outro, não deixava de impactar econômica e ambientalmente as águas e a cidade como um todo, na medida em que incorporou terras em benefício próprio e alterou condições naturais do rio e de córregos adjacentes que para o rio Pinheiros afluíam. A estas obras há que se adicionar, ainda, que em 1946 a empresa iniciou os trabalhos de alteamento da barragem da usina de Santana do Parnaíba, em 6.57 metros, com o objetivo de nos períodos chuvosos e com grande volume de águas, potencializar o volume de água direcionado (devido seu curso invertido) à represa Billings, para, então, ser utilizada na usina de Cubatão. Foi mais uma forma utilizada pela empresa para garantir sua capacidade geradora com o mínimo de investimento, especialmente nos momentos de escassez de chuvas. O alteamento foi concluído em 1954 e causou grande controvérsia com relação às inundações que aumentaram na cidade, ${ }^{28}$ na medida em que remansos eram formados ao longo do Tietê até a cidade de São Paulo (a $33 \mathrm{~km}$ ). Essa estrutura pode ser visualizada na figura 2 , na qual em vermelho encontra-se a usina de Santana do Parnaíba, onde houve o alteamento da barragem; em azul, a Estrutura do Retiro, cuja função era regular o trânsito das águas entre os rios Tietê e Pinheiros; no retângulo roxo, estão as represas Guarapiranga e Billings; e, em verde, a usina de Cubatão.

Em trabalhos anteriores, Santos $(2011,2015,2018)$ apresenta as discussões iniciais sobre a incorporação do espaço urbano na cidade de São Paulo em relação às águas da cidade, em especial no centro e na região do Brooklyn, as quais indicam que por mais que o processo de intervenções e canalizações de cursos d'água na cidade tenha origem em meados do século XIX, com as retificações e intervenções sobre o Tamanduateí, elas foram reproduzidas e intensificadas a partir da década de 1930, como se uma nova etapa se abrisse juntamente com o início da mudança no centro dinâmico de acumulação, como aponta Furtado (1953, p. 245).

Nessa nova fase, contudo, as intervenções, tanto do ponto de vista econômico, com a substituição de importações atreladas ao aumento da demanda por energia, quanto do ponto de vista urbanístico, com a abertura de ruas e avenidas, automobilização, aumento populacional etc., trazem consigo elementos de intervenção historicamente constituídos, mesmo que modeladas sobre teorias urbanísticas distintas, como a necessidade de se retificar as águas dos principais rios, tamponar córregos e ampliar as condições para investimentos privados. Continuidades e rupturas se mesclavam no processo histórico da transformação urbana.

O sentido, assim, em seus aspectos econômicos, sociais, ambientais manteve um caráter excludente e privatista em que -as águas, em especial- foram (e são) "domadas”, para acomodar a geração de energia e as incorporações orgânicas da terra ao conjunto da cidade, sendo a natureza ressignificada como "um subsistema da economia" (Marques, 2018, p. 135). Sentido que dinamizou e explica o palimpsesto recorrente na cidade, como na década de 1970, com a ree-

${ }^{28}$ Esta obra e a problemática dela decorrente encontra-se aqui apenas indicada e não será aqui detalhada devido à sua complexidade. Cabe salientar apenas que esta obra gerou grandes polêmicas com a intensificação das inundações na cidade de São Paulo, tendo, inclusive, fomentado a criação de uma Comissão Especial na Câmara Municipal para o Estudo das Enchentes em 1963. 


\section{FIGURA 2. PLANO GERAL DOS PRINCIPAIS EQUIPAMENTOS ESTRUTURAIS DA LIGHT NO ENTORNO DE SÃO PAULO, 1950}

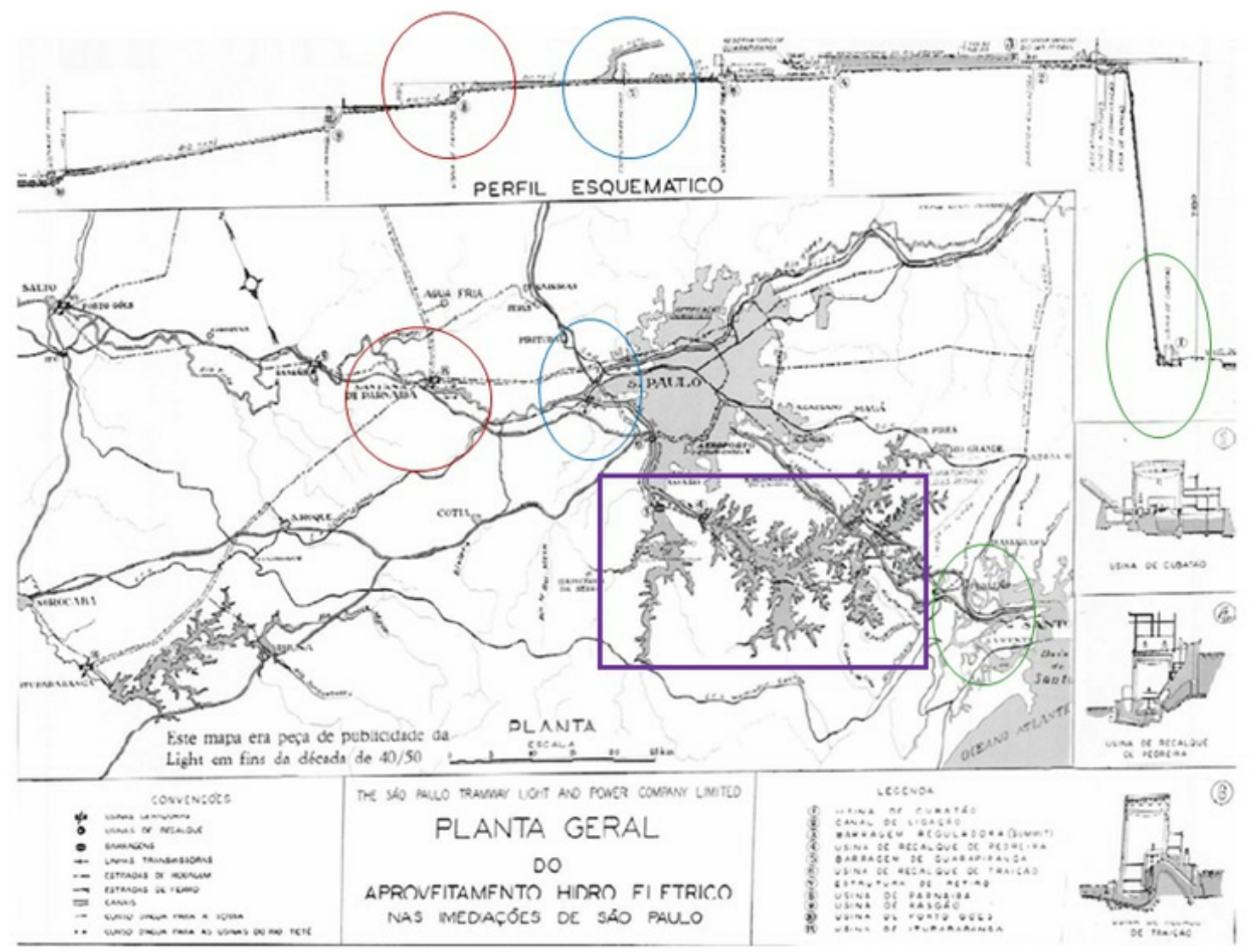

Fonte: Ackerman (1953).

laboração da região hoje conhecida como Vila Olímpia, próxima ao Brooklyn, por exemplo, a partir da construção do Centro Empresarial São Paulo (Cenesp) e das investidas da Bratke-Collet, transformando-a numa das áreas mais valorizadas da cidade; ou ainda as chamadas Operações Urbanas, como a Faria Lima (1995) e a Águas Espraiadas (2001), por exemplo.

\section{CONSIDERAÇÕES FINAIS}

Com o devido cuidado com a transposição conceitual referente a um tempo histórico para outro, o sentido da colonização formulado por Caio Prado Jr., é tratado aqui como arcabouço teórico e metodológico para se captar o longo tempo, de modo a apreender um conjunto de ações e fatos históricos que revelam um resultado ou, no limite, um padrão. Em outras palavras, engloba a tentativa de apreender e tentar compreender uma "linha mestra e ininterrupta de acontecimentos" para o entendimento do conjunto que, entre questões estruturais e conjunturais, possuem peculiaridades próprias e que são únicas para cada sociedade, período ou região. 
A referência conceitual, pensada com relação ao processo de ocupação urbana do final do século XIX às primeiras décadas do século Xx, fornece o suporte para a apreensão das dinâmicas impostas pela consolidação do sistema capitalista: pela atuação do capital privado -principalmente estrangeiro-, e pelas ações públicas -através das intervenções, planos, reformas, etcetera.

Evidentemente que no período em análise o incremento econômico e industrial associado às dinâmicas políticas e sociais apresentaram mudanças importantes, com distintas fases de desenvolvimento, como a passagem para uma nova fase de acumulação após os anos 1930, entretanto, a forma de as empresas e a municipalidade atuarem revelam continuidades e adequações aos diferentes contextos.

O Encilhamento e seus efeitos sobre os bens imobiliários parecem demonstrar como a terra se consolidava com um bem capaz de promover a reprodução do capital. Não à toa que naquele momento abrigou umas das primeiras manifestações especulativas com imóveis na Bolsa Livre, cujo exemplo pode ser o caso de Joaquim Eugenio de Lima, que após o fechamento da Bolsa investiu seus ganhos na aquisição das chácaras Bela Cintra e Pamplona, loteando grandes extensões de terra na região da atual avenida Paulista.

Os casos da City e da Light - com capitais estrangeiros- expressam um padrão de ocupação urbana com interferências sobre as águas. A primeira, ao incorporar considerável parcela de terras no início da década de 1910, criou as condições para interferências que foram do saneamento da área onde hoje se situa os bairros Jardins, passando pelo tamponamento do córrego do Pacaembu, até às relações estabelecidas com a Light para instalação de bondes em seus empreendimentos imobiliários, no caso do pagamento pela desapropriação dos terrenos oriundos da inundação de 1929.

Quanto à Light, a despeito de ter se instalado na cidade visando oferecer transporte urbano e logo passar a se dedicar à geração e distribuição energia elétrica (uma das matérias primas centrais para o desenvolvimento industrial), atuou e tentou impor seus interesses técnicos e políticos sempre que necessário, gerando conflitos com moradores e poderes públicos. Não à toa que sua área de concessão para distribuição de energia, na década de 1960, atingiu milhões de consumidores em 33 cidades em São Paulo e no Rio de Janeiro.

A comercialização das terras oriundas das desapropriações e da absorção das áreas pós-inundação de 1929, sob a rubrica TVP, revelam a magnitude do negócio com terras como parte das obras sobre o rio, demonstrando como a empresa considerava como sua propriedade a "terra do rio". Uma clara indicação de que o rio, na sua visão, era de sua propriedade, portanto, se terras do rio, suas mercadorias.

Do ponto de vista dos administradores públicos, as diferentes leis, os decretos, as regulamentações e obras de retificação de rios (Tamanduateí, Pinheiros e Tietê), o saneamento de várzeas justificadas na visão da cidade salubre e moderna, desde meados do século xIx, indicam um movimento em prol da construção da cidade ideal que deveria ser capaz de atrair e reproduzir capital. Sem mencionar os efeitos apenas apontados aqui do Plano de Avenidas, de Prestes Maia, que intensificou a ocupação dos fundos de vale.

Sob este contexto, portanto, as funcionalidades das águas também foram se reelaborando, de fontes de abastecimento para sobrevivência, comunicação, transporte, lazer, fontes para geração de renda etc. passaram cada vez mais a se tornar canais de descartes de resíduos, por isso incômodas e símbolos de insalubridade, mas também matéria prima essencial para a geração de energia. 
Cabe ressaltar que o ideal de cidade deveria passar pela difusão e aceitação social de suas benesses, como demonstrou o Jornal O Estado de São Paulo que efusivamente elogiou a conclusão das obras sobre o Pinheiros e seus ganhos. Em contrapartida, algumas vozes se levantavam direta ou indiretamente contra as ações da Light, por exemplo, como os engenheiros Catullo Branco ${ }^{29}$ e o Luiz Américo Pastorino, ${ }^{30}$ especialmente durante a apuração das inundações de 1963, realizada por uma comissão da Câmara Municipal criada especialmente para estudar o problema e sua constante recorrência.

Por fim, cabe destacar a incapacidade, ineficiência ou mesmo projeto deliberado de os poderes públicos não executarem um planejamento urbano capaz de integrar a miríade de problemas inter-relacionados que se apresenta(va)m, em seu conjunto e complexidade. Pois, como indica Costa (2003, p. 227) “o fato de não haver planejamento explícito não significa ausência de plano! Havia um planejamento corporativo. [...] A cidade de São Paulo estava sendo 'planejada' pelas 'corporações', talvez a Light seja o melhor exemplo”.

Talvez seja, mas não era a única. Salvo tentativas pontuais de algumas gestões públicas e de instituições ${ }^{31}$ que lutam por uma cidade mais humana e democrática. Na atualidade, os córregos e rios continuam alvos de tamponamentos e ou receptáculos de resíduos poluentes, os veículos automotores cada vez mais ordenam os rumos das obras urbanas, as inundações continuam a atormentar a população, especialmente as mais pobres sob altas condições de vulnerabilidade e sem direito à cidade. A nossa "síntese", portanto, é a de uma cidade antidemocrática, de caráter privado, essencialmente orientada para fins mercantis, que privatizou e continua a privatizar o espaço público em nome do negócio - uma cidade-mercadoria-, tratando cursos d'água como entes a serem escondidos porque poluídos, porque incomodam e porque não integram "a natureza urbanizada" sob a forma de concreto, prédios, avenidas, veículos.

\section{LISTA DE REFERÊNCIAS}

Ab’Sáber, A. N. (1958). O sítio urbano de São Paulo. En A. de Azevedo (ed.), A cidade de São Paulo: Estudos de geografia urbana (pp. 169-245). São Paulo: Nacional.

Ackerman, A. J. (1953). Billings and water power Brazil. Nueva York: America Society of Civil Engineers.

Alvim, Z. M. F. e Corrêa, D. S. (2000). A água no olhar da história. São Paulo: Secretaria do Meio Ambiente.

Arasawa, C. H. (2010). Uma cidade-capital: Práticas e estratégicas no campo urbanístico de São Paulo (1910-1945). En N. Odália e J. R. de C. Caldeira (eds.), História do estado de São Paulo: A formação da unidade paulista (pp. 343-363). São Paulo: Editora Unesp/Arquivo Público do Estado/Imprensa Oficial.

${ }^{29}$ Catullo Branco era engenheiro eletricista e, em 1928, ingressou na Secretaria de Viação e Obras Públicas de São Paulo. Em 1947, ele foi eleito deputado estadual pelo Partido Comunista Brasileiro. Era um ferrenho opositor do capital estrangeiro no Brasil que, segundo ele, apenas obstavam o desenvolvimento nacional ao buscar somente lucros e monopolizar serviços de utilidade pública. Na década de 1930 ele já chamava a atenção sobre importância da geração de energia de fonte eólica.

${ }^{30}$ Engenheiro, professor e membro da Sociedade Amigos da Cidade.

${ }^{31}$ Refiro-me essencialmente a organizações civis e movimentos sociais de toda ordem que lutam por melhores condições de vida, como movimentos por moradia, por mais verde, por revigoramento e despoluição de cursos d'água. 
Bacelli, R. (1982). A presença da Companhia City em São Paulo e a implantação do primeiro bairrojardim (Tese de mestrado). Universidade de São Paulo, São Paulo.

Bartalini, V. (2006). A trama capilar das águas na visão cotidiana da paisagem. Revista USP, 70, 88-97. DOI: 10.11606/issn.2316-9036.v0i70p88-97

Berman, M. (1986). Tudo que é sólido desmancha no ar: A aventura da modernidade. São Paulo: Companhia das Letras.

Bovo, J. M. (1974). Desenvolvimento econômico e urbanização. Influência do capital inglês na estrutura urbana de São Paulo (Tese de mestrado). Universidade de São Paulo, São Paulo.

Câmara dos Deputados do Estado de São Paulo. (1927). Projecto de Lei no 74 de 1927 que concede favores à The São Paulo Tramway Light and Power Company Limited.

Campos, C. M. (2002). Os rumos da cidade: Urbanismo e modernização em São Paulo. São Paulo: SENAC.

Castro, A. C. (1979). As empresas estrangeiras no Brasil: 1860-1913. Rio de Janeiro: Zahar.

Chalhoub, S. (1996). Cidade febril: Cortiços e epidemias na corte imperial. São Paulo: Companhia das Letras.

Corrêa, D. S. (2006). Historiadores e cronistas e a paisagem da colônia Brasil. Revista Brasileira de História, 26(51), 63-87. DoI: 10.1590/S0102-01882006000100005

Costa, L. A. M. (2003). O ideário urbano paulista na virada do século: O engenheiro Theodoro Sampaio e as questões territoriais e urbanas modernas (1886-1903). São Carlos: RiMa Editora.

Costa, W. (1998). A questão fiscal na transformação republicana: Continuidade e descontinuidade. Economia e Sociedade, 10, 141-173.

Custódio, V. (2012). Escassez de água e inundações na região metropolitana de São Paulo. São Paulo: Humanitas.

Elias, N. (1994). O processo civilizador: Uma história dos costumes (vol. 1). Rio de Janeiro: Zahar.

Ferla, L., Santos, F. A. D., Atique, F., Morais, D. D. S., Yamamoto, J., Rosin, M., Moraes, A. (2014). A enchente de 1929 na cidade de São Paulo: Memória, história e novas abordagens de pesquisa. Revista do Arquivo Geral da Cidade do Rio de Janeiro, 8, 149-166.

Freitag, B. (2012). Teorias da cidade. Campinas, São Paulo: Papirus.

Furtado, C. (1953). Formação econômica do Brasil. Brasília: Universidade de Brasília.

Gouveia, I. C. M. (2016). A cidade de São Paulo e seus rios: Uma história repleta de paradoxos. Confins, (27), 1-19. Dor: 10.4000/confins. 10884

Harvey, D. (2005). A produção capitalista do espaço. São Paulo: Annablume.

Harvey, D. (2013). Os limites do capital. São Paulo: Boitempo.

Hobsbawm, E. (1998). A era dos Impérios (1875-1914). São Paulo: Paz e Terra.

Iannone, R. A. (2006). Evolução do setor elétrico paulista (Doutorado). Universidade de São Paulo, São Paulo.

Jorge, J. (2006). Tietê, o rio que a cidade perdeu: São Paulo, 1890-1940. São Paulo: Alameda.

Lérias, R. A. (1988). O Encilhamento e a cidade de São Paulo, 1890-1891 (Tese de mestrado). Universidade de São Paulo, São Paulo.

Maffey, R. (1995). A Light e o controle das enchentes. História छீ Energia, 5, 72-85.

Marques, L. (2018). Capitalismo e colapso ambiental. Campinas: Edunicamp.

Martinez, P. H. (2006). História ambiental no Brasil: Pesquisa e ensino (vol. 130). São Paulo: Cortez.

McDowall, D. (2008). Light: A história da empresa que modernizou o Brasil. Rio de Janeiro: Ediouro Publicações. 
Mehrtens, C. (2003). Public and private, national and international: Crossed paths in São Paulo's process of urban consolidation, 1900-1940. En N. Randeraad (ed.), Formation and Transfer of Municipal Administraive Knowledge (pp. 13-39). Baden-Baden: Jahrbuch für Europäische Verwaltungsgeschichte.

Merhy, E. E. (1987). O capitalismo e a saúde pública: A emergência das práticas sanitárias no estado de São Paulo. Campinas: Papirus.

Needell, J. D. (1993). Belle époque tropical: Sociedade e cultura de elite no Rio de Janeiro na virada do século. São Paulo: Companhia das Letras.

Pádua, J. A. (2010). As bases teóricas da história ambiental. Estudos Avançados, 24(68), 81-101. DOI: $10.1590 / \mathrm{S} 0103-40142010000100009$

Pontes, J. A. (1995). Pinheiros: Do rio ao canal. História \&ீ Energia, 5, 1-15.

Prado Jr., C. (1997). Formação do Brasil contemporâneo. São Paulo: Brasiliense.

Romero, J. L. (2009). América latina: As cidades e as idéias. Rio de Janeiro: Universidade Federal do Rio de Janeiro.

Saes, A. M. (2010). Conflitos do capital: Light versus CBEE na formação do capitalismo brasileiro, 1898-1927. Bauru: Editora da Universidade do Sagrado Coração.

Saes, F. A. M. (1986). Café, indústria e eletricidade em São Paulo. História Eீ Energia, 1, 21-30.

Saes, F. A. M. e Szmrecsányi, T. (1995). El papel de los bancos extrangeiros em la industrialización inicial de São Paulo. En C. Marichal (ed.), Las inversiones extranjeras en América Latina, 18501930: Nuevos debates y problemas en historia económica comparada (pp. 230-243). México: Fondo de Cultura Económica.

Santos, F. A. (2011). Domando águas: Salubridade e ocupação do espaço na cidade de São Paulo, 18751930. São Paulo: Alameda/Fapesp.

Santos, F. A. dos. (2015). As inundações na região central da cidade de São Paulo: dinâmicas e significações (1850-1922). En J. Jorge (org.). Cidades paulistas. Estudos de história ambiental urbana (pp. 37-71). São Paulo. São Paulo: Alameda/ Fapesp.

Santos, F. A. (2018). Intervenções sobre o rio Pinheiros e a incorporação do espaço urbano nas primeiras décadas do século xx: O caso da região do Brooklin na cidade de São Paulo. Agua y Territorio, 11, 44-57. DOI: 10.17561/at.11.2953

Santos, M. (1998). A urbanização brasileira. São Paulo: Hucitec.

Schulz, J. (1996). A crise financeira da abolição, 1875-1901. São Paulo: Edusp/Instituto Fernand Braudel.

Seabra, O. C. L. (1987). Os meandros dos rios nos meandros do poder: Tietê e Pinheiros: Valorização dos rios e das várzeas na cidade de São Paulo (Doutorado). Universidade de São Paulo, São Paulo.

Seabra, O. C. L. (1998). Enchentes em São Paulo. Culpada Light? Memórias, 1(1), 21-24.

Senado do Estado de São Paulo. (1927). Projecto de Lei $n^{o} 74$ de 1927 que concede favores à The São Paulo Tramway Light and Power Company Limit.

Souza, C. (2006). Políticas públicas: Uma revisão da literatura. Sociologias, 16, 20-45. DoI: $10.1590 / \mathrm{S} 1517-45222006000200003$

Souza, M. C. P. (1988). O capital imobiliário e a produção do espaço urbano. O caso da Cia. City (Tese de mestrado). Fundação Getúlio Vargas, São Paulo.

Stiel, W. C. (1986). Metrô, velho desejo paulistano. História E̊ Energia, 3, 27-62.

Suzigan, W. (1986). Indústria brasileira: Origem e desenvolvimento. São Paulo: Brasiliense.

Szmrecsányi, T. (1986). A era dos trustes e cartéis. História \&̊ Energia, 1, 6-20.

Tannuri, L. A. (1977). O Encilhamento (Tese de mestrado). Universidade de Campinas. 
Telarolli jr., R. (1996). Poder e saúde: As epidemias e a formação dos serviços de saúde em São Paulo. São Paulo: Universidade Estadual Paulista.

The São Paulo Tramway, Light \& Power Co. Ltd. (1952). Annual Report-Relatório Annual. São Paulo: The São Paulo Tramway, Light \& Power Co. Ltd.

The São Paulo Tramway, Light \& Power Co. Ltd. (1958). Annual Report-Relatório Annual. São Paulo: The São Paulo Tramway, Light \& Power Co. Ltd.

The São Paulo Tramway, Light \& Power Co. Ltd. (1964). Annual Report-Relatório Annual. São Paulo: The São Paulo Tramway, Light \& Power Co. Ltd.

Veyret, Y. (2007). Os riscos o homem como agressor e vítima do meio ambiente. São Paulo: Contexto.

Worster, D. (1991). Para fazer história ambiental. Estudos Históricos, 4(8), 198-215. 